\title{
Molecular Methods for Assessement the Bacterial Communities from Different Type of Soils in Romania
}

\author{
Călina Petruța CORNEA' ${ }^{1}$, Cătălina VOAIDEȘ ${ }^{1}$, Matilda CIUCA' ${ }^{1}$, Vasilica \\ STAN $^{2}$, Eugenia GAMENT ${ }^{3}$, Iosif RAZEC ${ }^{4}$, Mirela DUŞA $^{2}$ \\ ${ }^{1}$ Center of Applied Biochemistry and Biotechnology, Department of Biochemistry, 011464 Bucharest, Romania; \\ ${ }^{2}$ University of Agronomic Sciences and Veterinary Medicine, 59 Bd Mărăşti, Sector 1, 011464, Bucharest, Romania; vstan@agro-bucuresti.ro \\ ${ }^{3}$ National Institut for Research and Development in Pedology, Agrochemistry and Environement, \\ Department of Soil Pollution, 61 Bd Mărăști, Sector 1, 011464, Bucharest, Romania \\ ${ }^{4}$ Institute of Research for Pasture, Braşov, 5 Cucului, Romania
}

\begin{abstract}
Rhizobia are soil bacteria that are capable to form nitrogen-fixing symbiosis with leguminous plants. This ability, as well as the diversity of microbial populations in the soil, and in the rhizosphere of host plants and non-host plants is influenced by several factors, including crop management. The aim of this work was the examination of the influence of some factors on indigenous populations of rhizobia in soils under different crop managements. The genetic diversity of rhizobial strains isolated directly from soil (free-living state) or from root nodules of three herbaceous perennial legumes was examined. The study was conducted in the experimental fields located in Moara Domnească area (South of Romania) and in the Brașov County. The characteristics of brown reddish soil were determined (nitrogen content, organic carbon content and $\mathrm{pH}$ ). Counting of the rhizobia populations was done by most probable number estimation and by viable plate counts. Bacterial strains were isolated directly from soil samples or from root nodules of different plant species (Trifolium repens, T. pratense and Lotus corniculatus). The characterization of rhizobia was performed by DNA fingerprinting (ERIC PCR and BOX PCR) and the bacterial diversity of soils was examined by DGGE technique. The results revealed that the rhizobial diversity was significantly lower in soils under increased fertilization with N. A reduced intraspecific polymorphism was observed in the strains recovered from the same plant species (Trifolium spp.), whatever the origin of the plant (Moara Domnească or Braşov) but clear differences appeared to be related to the origin of nodules (red or white clover) as revealed by DNA fingerprints. However, various amplicon profiles were observed by DGGE when total DNA isolated from soils was examined, the differences being associated with the fertilization level.
\end{abstract}

Keywords: molecular methods, $\mathrm{N}$ fertilization, Rhizobium leguminosarum biovar. trifolii

\section{Introduction}

Microbial soil communities play essential roles in various biogeochemical cycles, are responsible for the cycling of organic compounds and contribute to plant nutrition, plant health, soil structure and soil fertility (Kirk et al., 2004). Human activities, especially the agriculture, the use of fertilizers and pesticides, and pollution could affect the soil microbial communities, with significant consequences on plants and animals health. Among soil microorganisms with significant positive effects on plant, the legumenodulating bacteria are the most studied (McInnes et al., 2004). These bacteria are capable of fixing atmospheric nitrogen in specific root located structures, named nodules. Most of the legume-nodulating bacteria described so far, and known as "rhizobia," have been classified as belonging to the alpha Proteobacteria and to one of the six genera: Rhizobium, Sinorbizobium, Bradyrhizobium, Azorbizo- bium, Mesorbizobium, and Allorbizobium (Garrity and Lilburn, 2003; Rivas et al., 2009).

In order to study the microbial diversity, various methods could be used: plate counts; sole carbon source utilization patterns/community level physiological profiling for measuring microbial diversity; fatty acid methyl ester (FAME) analysis; molecular-based techniques. Among the molecular-based techniques to study microbial diversity could be mentioned the following: nucleic acid reassociation and hybridization, DNA microarrays, PCR-based approaches (denaturing gradient gel electrophoresisDGGE/temperature gradient gel electrophoresis-TGGE; single strand conformation polymorphism-SSCP; restriction fragment length polymorphism-RFLP/amplified ribosomal DNA restriction analysis-ARDRA; terminal restriction fragment length polymorphism-T-RFLP; ribosomal intergenic spacer analysis-RISA/automated ribosomal intergenic spacer analysis-ARISA; highly repeated 
sequence characterization or microsatellite regions) (Muyzer, 1999; Kirk et al., 2004). None of these methods offer all the information needed for the characterization of soil microbial diversity (structure and function of soil microorganisms) if they are used individually (McInnes et al., 2004). However, the molecular methods have an advantage against the other methods: they allow the identification not only of the cultivable microorganisms but also of the non-cultivable ones.

The microbial diversity with emphasize on rhizobia in various soils (natural, treated with different fertilizers, and pesticide, or subjected to different pollutants) was examined by using certain molecular methods like PCR-DGGE, T-RFLP, rep-PCR or ERIC PCR (Stark et al., 2007; Hartmann et al., 2007).

The aim of the present work was to examine the soil bacterial diversity in different experimental conditions (with or without the addition of chemical fertilizers) using both microbiological and molecular methods.

\section{Material and methods}

\section{Experimental site and soil preparation}

Two field experiments were considered. One of them was conducted in Braşov, at the Research Institute for Pasture, into a piedmont plain conditions with a chernozem (FAO classification) type soil, and the other one was conducted at Moara Domnească, at the Experimental Farm of the University of Agronomic Sciences and Veterinary Medicine of Bucharest, located in the Romanian Plain with a phaeozem type soil (FAO classification). In Braşov, soil samples were collected from an experimental field conditions cultivated with perennial legumes: white clover (Trifolium repens L.), red clover (Trifolium pratense L.), and bird's-foot trefoil (Lotus corniculatus L.). In this experimental field two type of nitrogen fertilization was used: with $50 \mathrm{~kg} \mathrm{Ha}^{-1} \mathrm{~N}$ and with $100 \mathrm{~kg} \mathrm{Ha}^{-1} \mathrm{~N}$. A control plot was carried without $\mathrm{N}$ fertilization. Each variant was carried out in three replicates. Soil samples were collected in both fields, Braşov and Moara Domnească, in 2010 summer (July). Two month before soil sampling no nitrogen fertilization was done. In Moara Domnească experimental field, soil samples were collected from an experimental field cultivated with red clover and white clover. All soils were sampled from the top $0-20 \mathrm{~cm}$.

\section{Soil analysis}

All soil samples were initially air-dried and sieved (2 $\mathrm{mm}$ size). Only the fraction $<2 \mathrm{~mm}$, which amounted to ca $98 \%$ of total soil weight, was used for further analysis. All soil $\mathrm{pH}$ measurements were done in $\mathrm{H}_{2} \mathrm{O}$ suspension (1:2.5) following potentiometric method. The organic carbon content was determined following Walkley-Black (1934) method, modified by Gogoasa (1959). The total nitrogen was determined by Kjeldahl method. The available phosphorus and potassium were determined by
Egnèr-Riehm-Domingo (1958) method. The soil chemical properties are presented as average of 4 samples for each location (Tab. 1).

Tab. 1. Some characteristics of soil from Braşov and Moara

Domnească

\begin{tabular}{ccc}
\hline & Moara Domnească soil & Braşov soil \\
\hline $\mathrm{pH}_{\mathrm{H} 2 \mathrm{O}}$ & 5.8 & 6.3 \\
$\mathrm{C} \%$ & 1.18 & 1.78 \\
$\mathrm{Nt} \%$ & 0.156 & 0.250 \\
$\mathrm{P}_{\mathrm{AL}}(\mathrm{ppm})$ & 7.72 & 9.7 \\
$\mathrm{~K}_{\mathrm{AL}}(\mathrm{ppm})$ & 96 & 101 \\
\hline
\end{tabular}

\section{Bacterial strains}

In experiments were used both, new strains isolated from red clover or white clover nodules, and a reference strain, Rhizobium leguminosarum biovar trifolii LMG 8820. Rhizobia were isolated from nodules of plants. Nodules were surface sterilized for $10 \mathrm{~min}$ in a solution of $90 \%(\mathrm{v} / \mathrm{v})$ ethanol followed by $10 \mathrm{~min}$ in a solution of $\mathrm{Na}$ hydrochloride at $0.5 \%(\mathrm{v} / \mathrm{v})$. Nodules were then washed three times with sterile distilled water. Nodules were crushed in approximately $0.1 \mathrm{ml}$ of sterile distilled water to release bacteroids. The bacteroid suspensions were plated on Mannitol-Yeast Extract-Congo red agar to obtain single colonies (Delorme et al., 2003). For the identification of the new isolates Api 20 NE kit and BIOLOG system were used, using $R$. leguminosarum biovar. trifolii LMG 8820 as reference.

\section{Culture conditions}

For in vitro studies, bacteria were cultivated in different media:

- YMA (10.0g/l mannitol; $1.0 \mathrm{~g} / \mathrm{l}$ yeast extract; $0.5 \mathrm{~g} / \mathrm{l}$ $\mathrm{K}_{2} \mathrm{HPO}_{4} ; 0.2 \mathrm{~g} / \mathrm{l} \quad \mathrm{MgSO}_{4} 7 \mathrm{H}_{2} \mathrm{O} ; 0.1 \mathrm{~g} / \mathrm{l} \mathrm{NaCl} ; 0.3 \mathrm{~g} / \mathrm{l}$ $\mathrm{CaCO}_{3} ; 15.0 \mathrm{~g} / 1$ agar, $\mathrm{pH}$ 7.0).

- YMA supplemented with $0.0025 \%$ Congo red or $0.00125 \%$ bromthymol blue.

The enumeration of soil bacteria was realized by the Most Probable Number Method (Vincent, 1970) and by determination of viable plate account $(\mathrm{CFU} / \mathrm{ml})$. The morphological traits evaluated comprised mucous production and colony morphology, $\mathrm{pH}$ change of the medium during growth of the isolates and growth rate. (Somasegaran and Hoben, 1985).

\section{Isolation of genomic DNA}

Total DNA was extracted from $5 \mathrm{ml}$ cultures of the bacterial isolates grown in yeast extract-mannitol broth at $30^{\circ} \mathrm{C}$, by applying the method of Rajasundari et al. (2009). The DNA samples were then used for PCR amplification using two types of primers recommended for repetitive regions from the bacterial genome: ERIC (ERIC 1R 5'-ATGTAAGCTCCTGGGGATTCAC-3'/ERIC2 5'-AAGTAAGTGACTGGGGTGAGCG-3') and 
66

BOX (BOXA1R 5'-CTACGGCAA GGCGACGCTGAGG-3'), the amplification conditions being described by de Bruijn (1992).

\section{Analysis of bacterial DNA from soil}

The isolation of DNA from soil samples was performed by applying three methods: the method of Yeates et al. (1998), the method of Orisini and Spica (2001) and ZR Soil Microbe DNA kit (Zymo Research). Preliminary examination of bacterial diversity was conducted by DGGE technique, using INGENYphorU system, according to Dilly et al. (2004). The primers and the amplification conditions used for amplification were recommended by Stark et al. (2007) for $\alpha$-proteobacteria: F203a (CCGCATACGCCCTACGGGGGAAAGATTTAT) /R1494 (CTACGGYTACCTTGTTACGAC) for the first PCR reaction and F984GC (AACGCGAAGAACCTTACCGCCCGGGGCGCGCCCCGGGCGGGGCG GGGGCACGGGGGG)/R1378 (CGGTGTGTACAAGGCCCGGGAACG) for the second one. DNA bands were stained with a solution of $0.5 \mu \mathrm{g} /$ $\mathrm{ml}$ ethidium bromide and examined under UV light with BioDocIt UVP.

\section{Results and discussion}

\section{Influence of soil treatments on bacterial communities}

Microbial diversity in soils is considered important for maintaining sustainability of agricultural production systems. Studies conducted in different geographic area relieved that farming practices, commonly associated with organic farming have a positive effect on the soil microbial diversity and soil processes. It was shown also that leguminous plants are often part of crop rotations, either as components of the pasture phase (e.g. clover) or as green manure crops, which add very useful organic matter to the soil after incorporation (Stark et al., 2007). However, despite the studies performed by various researches, the links

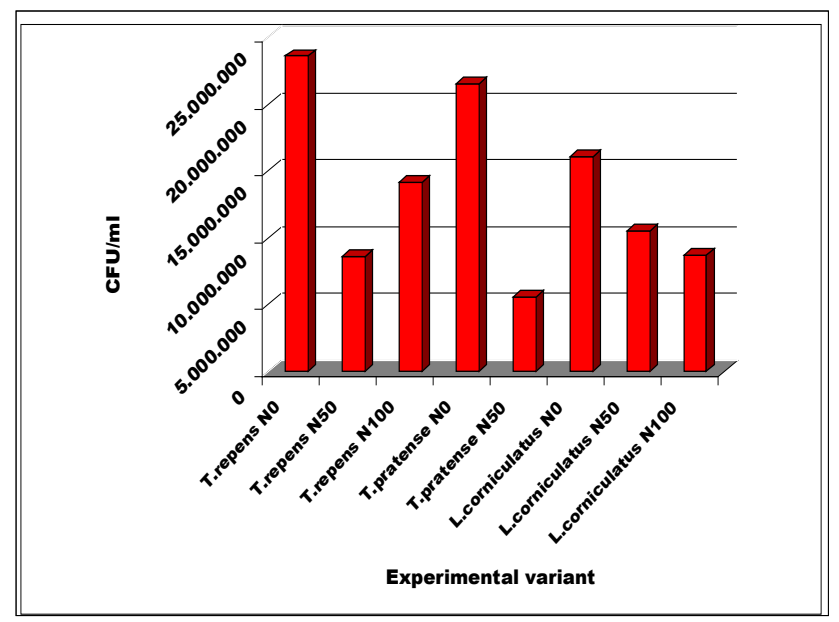

Fig. 1. Variation of the number of the bacterial colonies developed on YMA plates, related on the plant species and the fertilization level (N0, N50 and N100) between microbial diversity and ecosystem processes are not well understood. In this respect, the first aspect examined during the experiments was the evaluation of the bacteria content and diversity in soils subjected to the chemical fertilization.

When the number of bacteria and the diversity of the colonies developed on YMA plates were examined, differences between control and experimental variants were encountered (Fig. 1).

Differences observed seem to be related to the plant species examined. For both clover species, the highest decrease of bacterial number was observed in the variant N50 (Fig. 1), compared to bird's-foot trefoil when the $\mathrm{N} 100$ shown the lowest number of CFU/ml.

Regarding the diversity of the colonies developed on YMA plates, the increase of the nitrogen fertilizer rate determined the reduction of the diversity, the number of mucous, translucent colonies being very small or absent (Fig. 2).

Another observation was related to the number of nodules on the roots of leguminous species examined: it was noted that the number and the dimension of these nodule decreased with the increase of fertilizer level.

The results obtained in these experiments were comparable with those reported by other researchers. Stark et al. (2007) observed that the presence or absence of $\mathrm{N}$ substrate had a strong effect on the community structure of bacteria and actinomycetes, while the influence of fertilizer type was less pronounced. High levels of nitrogen in the soil are thought to decrease the diversity of rhizobia in the soil (Palmer and Young, 2000). Moreover, according to Barabasz et al. (2002), high $\mathrm{N}$ rates reduced the number of bacteria and actinomycete species, but the change in the number of fungal species was negligible. They demonstrated that high mineral $\mathrm{N}$ fertilizers rates determine the recession of bacteria of the genera Arthrobacter and Streptomyces by $50 \%$ on average and complete eradication of bacterial genera Azotobacter, Rhizobium and Bradyrhizobium. Similar results were obtained in present experiments: high level of $\mathrm{N}$ fertilizers induced the reduction of the number of the soil bacteria, especially of the rhizobia.

\section{Isolation and molecular characterization of some strains} of Rbizobium leguminosarum biovar trifolii

In order to examine the molecular polymorphism among rhizobia, that induced the nodule formation on the leguminous species examined, several nodules from each species were used for bacteria isolation, according to Delorme et al. (2003). The method applied was efficient and allowed the isolation of more than 100 colonies that, after 3 to 5 day of growth on YMA at $28^{\circ} \mathrm{C}$, they did not accumulate Congo red and acidified the medium containing bromthymol blue. The colonies were circular, with regular borders, creamy in color and with high production of exoplysaccharides. Among them, six colonies were ran- 

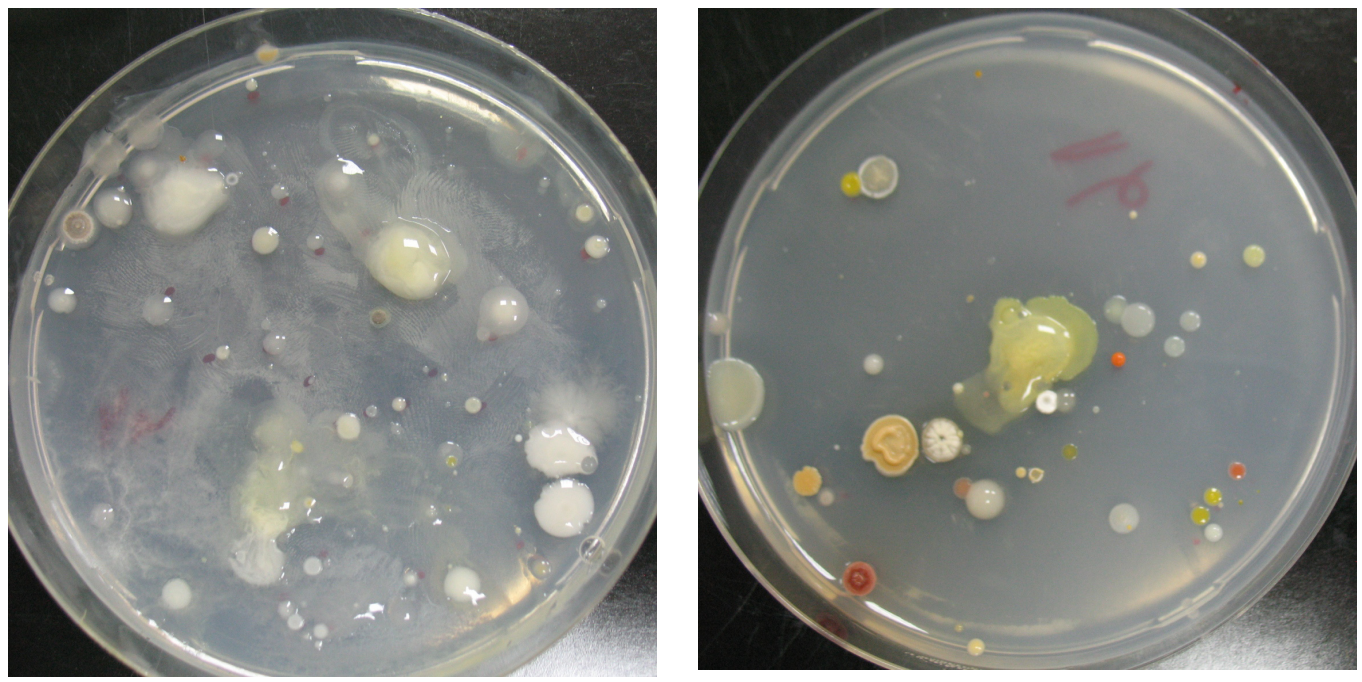

Fig. 2. Difference on the number and bacterial diversity in soil cultivated with L. corniculatus, variant N0

(left) and N100 (right), respectively

dom chosen and designated as R1, R2, R3, R4, R5 and R6 (Tab. 2).

All of these colonies were subjected to the identification with both Api 20NE kit and Biolog (MicroLog) system, using $R$. leguminosarum biovar trifolii LMG 8820 as reference strains. All the morphological, phenotype characteristics (according to the latest information) (Reeve et al., 2010) and biochemical data allowed the conclusion that they belong to $R$. leguminosarum biovar trifolii.

The next step in the investigation was the isolation of total DNA in order to determine the intraspecific polymorphism. The method used in the experiments was efficient for all the strains tested, even the quantity of bacterial DNA was different (the lowest was observed in R1 sample) (Fig. 3).

The microbiological data were confirmed by ITSPCR-RFLP, using HaeIII restriction enzyme for cleavage of the amplicons obtained with ITS1/ITS2 primer pair (data not shown). Previous studies on rhizobia isolated from nodules from various plant legumes proved both, interspecific and intraspecific molecular polymorphism (both at plasmidial or genomic level) and led to establish genetic relationship between isolates as well as correlation with environmental conditions (Laguerre et al., 1996; Tebbe and Schloter, 2007). Generally, various molecular methods could be used for the detection of intraspecific polymorphism (Thies, 2004). The utility of PCR analysis using arbitrary primers or primers related to the repetitive sequences from bacterial DNA (rep-PCR, ERIC or BOX primers) to determine genetic relationships among nodule-forming bacteria, including $R$. leguminosarum biovar trifolii, was demonstrated by various authors (de Bruijn, 1992; Simon, 2006; Ogutcu et al., 2009). However, the variability of RAPD markers between different authors has limited their relevance and acceptance (Laguerre et al., 1996). More useful seems to be the analysis of naturally occurring interspersed repetitive DNA elements (Versalovic et al., 1991, 1994; de Bruijn, 1992). Three types of repetitive sequences have been described in most detail: the 35-40 bp repetitive extragenic palindromic (REP) sequence, the 124-127 bp enterobacterial repetitive intergenic consensus (ERIC) sequence, and the $154 \mathrm{bp} \mathrm{BOX}$

Tab. 2. Morphological and cultural traits of isolates of $R$. leguminosarum biovar trifolii

\begin{tabular}{|c|c|c|c|c|c|c|c|}
\hline $\begin{array}{l}\text { Isolate } \\
\text { No. }\end{array}$ & Plant host & $\begin{array}{l}\text { Treatment and } \\
\text { geographical } \\
\text { origin }\end{array}$ & $\begin{array}{l}\text { Gram } \\
\text { reaction }\end{array}$ & $\begin{array}{l}\text { Colony } \\
\text { color }\end{array}$ & $\begin{array}{c}\text { Mucous } \\
\text { aspect }\end{array}$ & $\begin{array}{l}\text { Colour of bromthymol } \\
\text { blue containing medium } \\
\text { inoculated with rhizobia }\end{array}$ & $\begin{array}{c}\text { Colony colour } \\
\text { on Congo red } \\
\text { containing medium }\end{array}$ \\
\hline $\mathrm{R} 1$ & T. pratense & $\begin{array}{l}\text { No fertilization; } \\
\text { Braşov }\end{array}$ & - & creamy & + & yellow & white \\
\hline $\mathrm{R} 2$ & T. pratense & $\begin{array}{l}\text { No fertilization; } \\
\text { Moara Domnească }\end{array}$ & - & creamy & + & yellow & white \\
\hline R3 & T. pratense & $\begin{array}{l}\text { N50 fertilization; } \\
\text { Braşov }\end{array}$ & - & creamy & + & yellow & white \\
\hline $\mathrm{R} 4$ & Trepens & $\begin{array}{l}\text { No fertilization; } \\
\text { Braşov }\end{array}$ & - & creamy & + & yellow & white \\
\hline R5 & T. repens & $\begin{array}{l}\text { No fertilization; } \\
\text { Moara Domnească }\end{array}$ & - & creamy & + & yellow & white \\
\hline R6 & T. repens & $\begin{array}{l}\text { N50 fertilization; } \\
\text { Braşov }\end{array}$ & - & creamy & + & yellow & white \\
\hline
\end{tabular}


68

elements (Versalovic et al., 1994). In order to study these sequences located in distinct, intergenic positions all around the chromosome, various PCR primers have been designed (Versalovic et al., 1994). The use of such primers in PCR reactions leads to the selective amplification of distinct genomic regions located between REP, ERIC or BOX sequences (de Bruijn et al., 1996).

In the present experiments, ERIC and BOX primers were used. Significant results were obtained with BOX $1 \mathrm{R}$ primer: 2-12 fragments ranged from around 200 to 2000 bp were revealed (Fig. 4).

The results lead to the conclusion that the strains $\mathrm{R} 1$, $\mathrm{R} 2$ and R3, isolated from red clover nodules, exhibit similar amplicons, but their profiles present some differences comparing with the reference strain. For R4, R5 and R6 strains, isolated from white clover, the amplicons obtained presented variation in length and number, but common

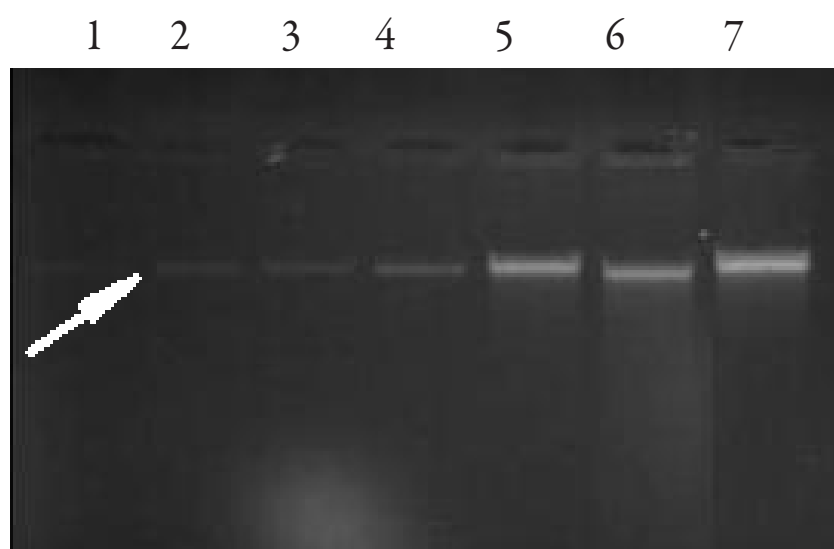

Fig. 3. Total DNA isolated from $R$. leguminosarum biovar trifolii strains: 1-6: R1-R6; 7-R. leguminosarum biovar trifolii LMG 8820

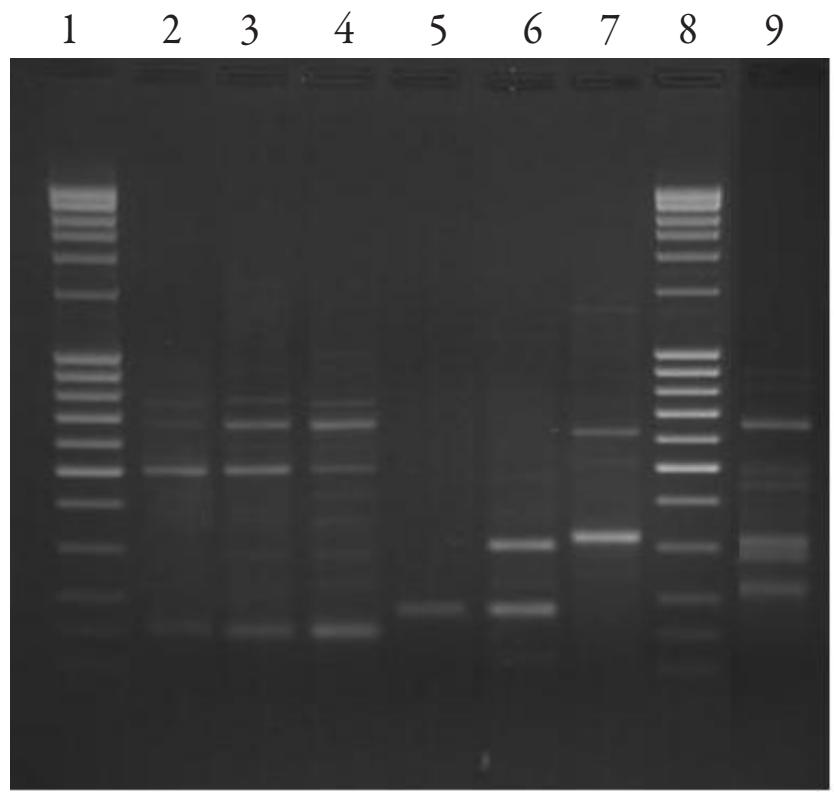

Fig. 4. BOX-PCR electrophoretic profile: $1,8-1 \mathrm{kbp}$ DNA ladder (Fermentas); 2-7: R1-R6 strains; 9-reference strain R. leguminosarum biovar trifolii LMG 8820
DNA bands with R1, R2 and R3 strains, as well as with the reference strain could be detected. No significant differences between R1 and R2 strains, originated from two Romanian regions, were observed (Fig. 4). Moreover, the nitrogen fertilization had no effect on $\mathrm{BOX}$ repetitive sequences.

Similar results were obtained whit ERIC primers but the number of amplicons detected was lower than in BOX-PCR. Based on BOX-PRC and ERIC-PCR, the strains examined could be included in three different clusters: one includes the strains isolated from red clover; the second includes the isolated from white clover, and the third, the reference strain.

The present data data supported the previous studies reporting that rep-PCR genomic fingerprinting is an adequate technique for differentiating rhizobial strains. According to the results, BOX-PCR proved to be the best fingerprinting method for the determination of genomic diversity among $R$. leguminosarum biovar trifolii.

\section{Molecular analysis of microbial communities from natural and fertilized soils}

Another aspect examined was to detect the possible modification of $\alpha$-proteobacteria soil communities, as a consequence of nitrogen fertilization. A critical step in such studies is the DNA isolation. The direct DNA extraction from soil is based on in situ lysis of bacterial strains in the presence of soil, followed by separation of the nucleic acids from matrix components and cell debris. Despite the simplicity of these methods and the highest yields of DNA, the extracted DNA often contains considerable amounts of humic acids and other substances that could interfere with the subsequent molecular tests. Several methods were developed to overcome this contamination (Lakay et al., 2007).

In the present experiments, three methods for DNA extraction were tested: the first method involved the bead beating of soil samples (Yeates et al., 1998); the second involve the microwave treatments, according to Orsini and Spica (2001); the third one was represented by the commercial soil DNA extraction kit (ZR Soil Microbe DNA kit). Comparing the results (quantity and quality of DNA extracted) it could be assumed that the most rapid method was the second one, but the most efficient (from both points of view) was the third one (Fig. 5).

Total DNA extracted from different types of soils was used in further analysis, involving the DGGE technique (Nakatsu, 2007). The denaturing gradient gel electrophoresis (DGGE) is based on the electrophoretic separation (in a polyacrylamide gel containing a linear gradient of DNA denaturants) of a mixture of PCR products. These amplicons were obtained using genomic DNA extracted from a complex community of microorganisms, using primers specific for a molecular marker, such as the $16 \mathrm{~S}$ rRNA gene (Muyzer, 1999). In this method DNA fragments of the same length, but with different sequences, 
can be separated. The separation is based on the decreased electrophoretic mobility of a partially melted double stranded DNA molecule in polyacrylamide gels containing a linear gradient of DNA denaturants (a mixture of urea and formamide) or a linear temperature gradient (Muyzer and Smalla, 1998). In order to improve the separation of DNA strands, a sequence of guanines $(G)$ and cytosines (C) is added to the $5^{\prime}$ end of one of the PCR primers, co-amplified and thus introduced into the amplified DNA fragments (GC clamp). The length of the GC clamp can vary between 30 and 50 nucleotides and it acts as a high melting domain preventing the two DNA strands from complete dissociation into single strands (Muyzer and Smalla, 1998; de Oliveira et al., 2006).

In the present experiments, specific primers for $\alpha$-proteobacteria and a particular GC clamp were used for DNA amplification (for $16 \mathrm{~S}$ rRNA genes), according to Stark et al. (2007). DNA extracted from eight soil samples was analyzed by DGGE. The samples were: soil cultivated with $T$. repens, without fertilization (N0) (V1); soil cultivated with $T$. repens, with fertilization N50 (V2); soil cultivated with $T$. repens, with fertilization N100 (V3); soil

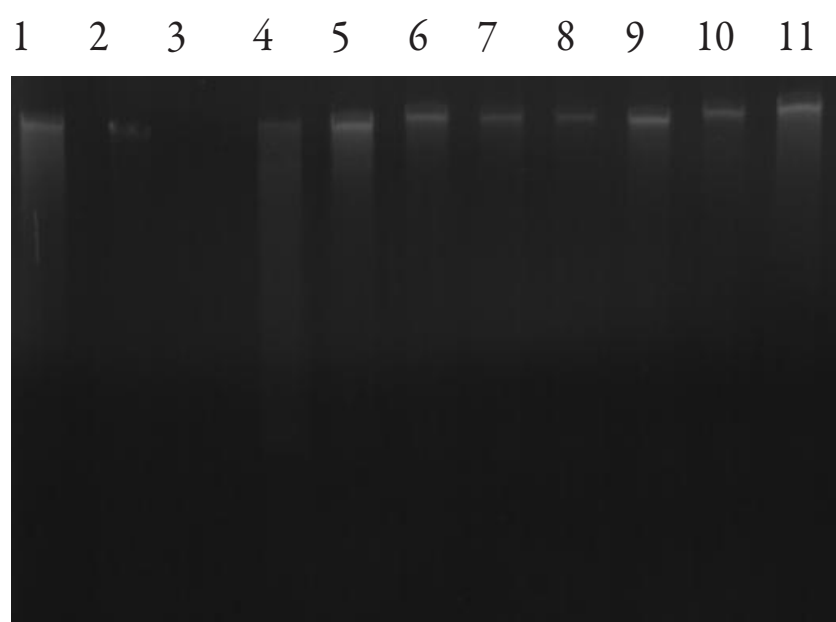

Fig. 5. DNA extraction by using the three methods: 1-3-the method described by Yeates et al. (1998); 4-7-the methods of Orsini and Spica (2001); 7-11-ZR Soil Microbe DNA kit

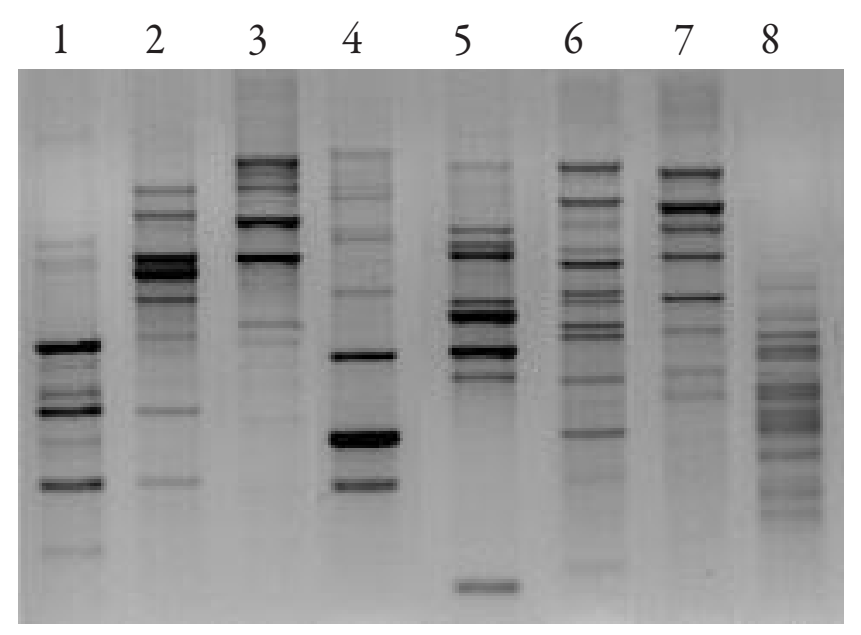

Fig. 6. DGGE pattern of amplicons obtained starting eight DNA soil samples (negative image) cultivated with $T$. pratense without fertilization (V4); soil cultivated with $T$. pratense with fertilization N50 (V5); soil cultivated with Lotus corniculatus without fertilization (V6); soil cultivated with $L$. corniculatus with fertilization N50 (V7); soil cultivated with $L$. corniculatus with fertilization N100 (V8). The preliminary results obtained suggest that the increase of fertilization level induced changes in the DNA bands pattern. In V1-V3 samples (soils cultivated with $T$. repens), larger DNA bands were dominant when the fertilizers were applied, comparing with the untreated soil (Fig. 6). Similar results were observed in V4 and V5 samples (soils cultivated with T. pratense). Contrary, in V6, V7 and V8 samples (soils cultivated with $L$. corniculatus), only the highest level of fertilization induced modifications in DNA pattern, but smaller DNA band dominated.

These results could be considered to be in accord with the previous data on bacterial diversity detected by cultivation method. The reduced number of DNA bands from unfertilized samples observed after DGGE, compared with the results obtained by other authors (Laguere $e t$ al., 1996; Dilly et al., 2004; de Oliveira et al., 2006; Tebbe and Schloter, 2007; Ascher et al., 2010) could be explained by the specificity of primers used in experiments: they are recommended for $\alpha$-proteobacteria and it is possible that the samples contain also different groups of bacteria. However, it is not clear if the modifications observed are strictly related to the nitrogen fertilization or are influenced by the soil management history. According to other authors (Stark et al., 2007) the presence or absence of $\mathrm{N}$ substrate had a strong effect on the community structure of bacteria, while the influence of fertilizer type was less pronounced.

\section{Acknowledgements}

This research was supported by the project ECODIVERGEN (Contract number 32-147/2008 financed by the Romanian National Research Plan-II, the Programe 4-Partenership, respectively).

\section{References}

Ascher J, Ceccherini MT, Chronakova A, Jirout J, Borgogni F, Elhottova D, Simek M, Pietramellara G (2010). Evaluation of the denaturing gradient gel electrophoresis apparatus as a parameter influencing soil microbial community fingerprinting. World J Microbiol Biotechnol 26:17211726.

Barabasz W, Albińska D, Jaśkowska M, Lipiec J (2002). Biological Effects of Mineral Nitrogen Fertilization on Soil Microorganisms. Polish J Environ Studies 11(3):193-198.

De Bruijn FJ (1992). Use of repetitive (repetitive extragenic palindromic and enterobacterial repetitive intergeneric consensus) sequences and the polymerase chain reaction to fingerprint the genomes of Rhizobium meliloti isolates and other soil bacteria. Appl Environ Microbiol 58:2180-2187.

De Bruijn FJ, Rademaker J, Schneider M, Rossbach U, Louws FJ (1996), p. 497-502. In: Stacey G, Mullin B, Gresshoff 
70

P (Eds.). Rep-PCR Genomic Fingerprinting of PlantAssociated Bacteria and Computer-Assisted Phylogenetic Analyses, Biology of Plant-Microbe Interaction; Proceedings of the $8^{\text {th }}$ International Congress of Molecular Plant-Microbe Interactions.

De Oliveira VM, Manfio GP, Da Costa Coutinho HL, KeijzerWolters AC, Van Elsas JD (2006). A ribosomal RNA gene intergenic spacer based PCR and DGGE fingerprinting method for the analysis of specific rhizobial communities in soil. J Microbiol Methods 64:366-379.

Delorme CA, Gagliardi JV, Angle JS, van Berkum P, Chaney RL (2003). Phenotypic and Genetic Diversity of Rhizobia Isolated from Nodules of Clover Grown in a Zinc and Cadmium Contaminated Soil. Soil Sci Soc Am J 67:17461754.

Dilly O, Bloem J, Vos A, Munch JC (2004). Bacterial Diversity in Agricultural Soils during Litter Decomposition. Appl Environ Microbiol 70:468-474.

Garrity GM, Bell JA, Lilburn TG (2003). Taxonomic outline of Prokaryotes. In: Garrity GM (Ed.). Bergey's manual of systematic bacteriology. $2^{\text {nd }}$ Edn. Springer, New York

Hartmann A, Smalla K, Sørensen J (2007). Microbial Diversity in the Rhizosphere: Highly Resolving Molecular Methodology to Study Plant-Beneficial Rhizosphere Bacteria, p.102-130. In: Benckiser G, S Schnell (Eds.). Biodiversity in agricultural production systems, CRC Press Taylor and Francis Group.

Kirk JL, Beaudette LA, Hart M, Moutoglis P, Klironomos JN, Lee H, Trevors JT (2004). Methods of studying soil microbial diversity. J Microbiol Methods 58:169-188.

Laguere G, Mavingui P, Allard MR, Charnay MP, Louvrier P, Mazurier SI, Rigotier-Gois L, Amarger N (1996). Typing of Rhizobia by PCR DNA Fingerprinting and PCRRestriction Fragment Length Polymorphism Analysis of Chromosomal and Symbiotic Gene Regions: Application to Rhizobium leguminosarum and its Bifferent Biovars. Appl Environ Microbiol 62:2029-2036.

Lakay FM, Botha A, Prior BA (2007). Comparative analysis of environmental DNA extraction and purification methods from different humic acid-rich soils. J Appl Microbiol 102:265-273.

McInnes A, Thies JE, Abbott LK, Howieson JG (2004). Structure and diversity among rhizbial strains, populations and communities-a review. Soil Biol Biochem 36:12951308.

Muyzer G (1999). Genetic fingerprinting of microbial communities-present status and future perspectives. In: Bell CR, Brylinsky M, Johnson-Green P (Eds.). Microbial Biosystems: New Frontiers, Proceedings of the $8^{\text {th }}$ International Symposium on Microbial Ecology Atlantic Canada Society for Microbial Ecology, Halifax, Canada.

Muyzer G, Smalla K (1998). Application of denaturing gradient gel electrophoresis (DGGE) and temperature gradient gel electrophoresis (TGGE) in microbial ecology, Antonie van Leeuwenhoek 73:127-141.
Nakatsu CH (2007). Soil microbial community analysis using denaturation gradient gel electrophoresis. Soil Sci Soc Am J 71:562-571.

Ogutcu H, Adiguzel A, Gulluce M, Karaday M, SahinF (2009). Molecular Characterization of Rhizobium Strains Isolated from Wild Chickpeas Collected from High Altitudes in Erzurum-Turkey. Romanian Biotechnological Letters 14:4294-4300

Orsini M, Romano-Spica V (2001). A microwave-based method for nucleic acid isolation from environmental samples. Letters in Applied Microbiology 33:17-20.

Palmer KM, Young JPW (2000). Higher diversity of Rhizobium leguminosarum Biovar viciae in arable soils than in grass soils. Appl Environ Microbiol 66:2445-2450.

Rajasundari K, Ilamurugu K, Logeshwaran P (2009). Genetic diversity in rhizobial isolates determined by RAPDs. African J Biotechnol 8:2677-2681.

Reeve W, O’Hara G, Chain P, Ardley J, Bräu L, Nandesena K, Tiwari R, Malfatti S, Kiss H, Lapidus A, Copeland A, Nolan M, Land M, Ivanova N, Mavromatis K, Markowitz V, Kyrpides N, Melino V, Denton M, Yates R, Howieson J (2010). Complete genome sequence of Rhizobium leguminosarum bv trifolii strain WSM2304, an effective microsymbiont of the South American clover Trifolium polymorphum. Stand Genomic Sci 2:66-76.

Rivas R, García-Fraile P, Velázquez E (2009). Taxonomy of Bacteria Nodulating Legumes. Microbiol Insights 2:51-69

Simon T (2006). New Rhizobium leguminosarum bv. trifolii isolates: collection, identification and screening of efficiency in symbiosis with clover. Plant Soil Environ 52:105-110 .

Somasegaran P, Hoben HJ (1985). Methods in legumeRhizobium technology. http://www.ctahr.hawaii.edu/bnf/ rhizobium_technology.asp.

Stark C, Condron LM, Stewart A, Di HJ, Callaghan MO (2007). Influence of organic and mineral amendments on microbial soil properties and processes. Appl Soil Ecol 35:79-93.

Tebbe CC, Schloter M (2007). Discerning the Diversity of Soil Prokaryotes (Bacteria and Archaea) and Their Impact on Agriculture, p. 81-101. In: Benckiser G, Schnell S. Biodiversity in agricultural production systems,CRC Press Taylor and Francis Group.

Versalovic J, Koeuth T, Lupski JR (1991). Distribution of repetitive DNA sequences in eubacteria and application to fingerprinting of bacterial genomes. Nuc Acids Res 19:68236831.

Versalovic J, Schneider M, de Bruijn FJ, Lupski JR (1994). Genomic fingerprinting of bacteria using repetitive sequence based PCR (rep-PCR). Meth Cell Mol Biol 5:25-40.

Vincent JM (1970). A manual for the practical study of rootnodule bacteria, IBP Handbook no. 15, Blackwell Sci Pub.

Yeates C, Gillings MR, Davison AD, Altavilla N, Veal DA (1998). Methods for microbial DNA extraction from soil for PCR amplification. Biological Procedures Online 1(1): www.biologicalprocedures.com. 